\title{
Relationship between Diabetic Retinopathy, and Diabetic Nephropathy
}

\author{
*Debnath $\mathrm{PR}^{1}$, Debnath $\mathrm{DK}^{2}$, Bhowmik NC ${ }^{3}$
}

\begin{abstract}
Diabetic nephropathy is accountable for nearly third of the world cases of last step of renal disease; it becomes a major public health problem with social and economic burden. To assess the relationship between Diabetic Retinopathy and Diabetic Nephropathy in Type II Diabetes Mellitus patients. The present study was a cross sectional study conducted in the department of Ophthalmology at BIRDEM General Hospital, Dhaka, over a period of 12 months during March 2018February' 2019 and were assess for the relationship between Retinopathy and Nephropathy. All patients of Type II Diabetes Mellitus patients with Diabetic Retinopathy and Diabetic Nephropathy were included in the study. Majority (64.0\%) patients had diabetic nephropathy and 36(36.0\%) had not diabetic nephropathy. Almost three fourth (73.4\%) patients was found diabetic retinopathy in diabetic retinopathy and $27(54.0 \%)$ in without diabetic retinopathy. The difference was statistically significant $(p<0.05)$ between two group. This study suggests that Diabetic Nephropathy has a significant association with the presence of Diabetic Retinopathy in persons with Type II DM.
\end{abstract}

Keywords: Diabetic Nephropathy, Diabetic Retinopathy, Type II Diabetes Mellitus, Microalbuminuria

\section{INTRODUCTION}

Diabetes mellitus is one of the most familiar metabolic disorders of several etiologies. The multisystem special effects of diabetes such as nephropathy, retinopathy, neuropathy and cardiovascular diseases have a significant impinging on the working age individuals in our country. ${ }^{1}$

Diabetic nephropathy is accountable for almost third of the world cases of end stage renal disease; it is a foremost public health problem which also social and financial burden. ${ }^{2}$ Diabetes is multi system disorder which can

1. *Dr. Purabi Rani Debnath Associate Prof. \& Unit Head, Dept. of Ophthalmology, BIRDEM General Hospital. E-mail: debnathpurabi@yahoo.com

2. Dr. Dilip kumar Debnath, Associate Prof. \& Unit Head, Dept. of Ophthalmology ,DMCH.

3. Dr. Narayan Chandra Bhowmik, Senior Medical Officer, BIRDEM General Hospital, Dhaka.

*For correspondence effected both eyes and kidneys. Glomerular filtration rate (GFR) and microalbuminuria are clinically important markers for the assessment of renal function. ${ }^{3}$ Diabetic nephropathy is defined when GFR is less than $60 \mathrm{ml}$ in occurrence of proteinuria. ${ }^{4}$

Duration of disease is the most important risk factor; type 1 DM patients express diabetic retinopathic changes after a common period of 3-5 years of beginning of systemic disease. In type $2 \mathrm{DM}$ patients, the time of onset and therefore length have been more complicated to determine accurately, so newly diagnosed type 2 DM patients infrequently present with retinopathy as initial sign of DM.

\section{METHODOLOGY:}

The study was a cross sectional study conducted in the department of Ophthalmology at BIRDEM General Hospital, Dhaka, over a period of 12 months during March 2018- February' 2019 and were evaluate for the association between Retinopathy and Nephropathy.

\section{Inclusion criteria:}

- All patients of Type II Diabetes Mellitus patients

- Diabetic Retinopathy.

- Diabetic Nephropathy.

\section{Exclusion criteria:}

- Patients with Type 1 Diabetes Mellitus,

- Retinopathy due to other causes,

- Nephropathy due to other causes.

Total 100 cases were studied over 3 years. Relevant assessment like Slit Lamp Bio microscopy, Visual acuity, Fundoscopy by Direct and Indirect ophthalmoscope, Blood Parameters, Urine albumin FFA, 24 hours urinary protein and Renal Biopsy were done.

\section{RESULTS:}

Approximately half $(52.0 \%)$ of the patients were male and $48.0 \%$ were female. The mean age was found $57.5 \pm 10.9$ years with the range from 39 to 85 years (Table-I). Majority (42.0\%) patients was found NPDR, 24(24.0\%) 
was PDR and 34(34.0\%) was no DR in diabetic retinopathy (Table-II). Majority (64.0\%) patients had diabetic nephropathy and 36(36.0\%) had not diabetic nephropathy (Table-III). Sixty nine (69.0\%) patients were hypertension and 21(21.0\%) were smoker. Mean BMI was found $26.0 \pm 3.0 \mathrm{~kg} / \mathrm{m}^{2}$, FBS was $7.5 \pm 2.8 \mathrm{mmol} / \mathrm{l}, 2 \mathrm{HABS}$ was $11.7 \pm 4.8 \mathrm{mmol} / \mathrm{l}$, HbAlc was $7.4 \pm 1.8$ percent, systolic blood pressure was $135.8 \pm 21.7 \mathrm{mmHg}$, diastolic blood pressure was found $81.9 \pm 11.9$, triglycerides was $180.9 \pm 97.2 \mathrm{mg} / \mathrm{dl}$, total cholesterol was $192.1 \pm 31.6$ $\mathrm{mg} / \mathrm{dl}$, LDL was $104.7 \pm 34.3 \mathrm{mg} / \mathrm{dl}$, eGFR was $42.2 \pm 38.3$ $\mathrm{mg} / \mathrm{dl}$ and serum creatinine was $1.8 \pm 0.9 \mathrm{mg} / \mathrm{dl}$ (Table-IV). Almost three fourth (73.4\%) patients was observed diabetic retinopathy in diabetic retinopathy and $27(54.0 \%)$ in without diabetic retinopathy. The difference was statistically significant $(\mathrm{p}<0.05)$ between two groups (Table-V).

Table-I : Demographic characteristics of the study patients $(n=100)$

\begin{tabular}{|l|c|c|c|}
\hline \multicolumn{2}{|l|}{$\begin{array}{l}\text { Demographic } \\
\text { characteristics }\end{array}$} & $\begin{array}{c}\text { Number of } \\
\text { patients }\end{array}$ & Percentage \\
\hline \multirow{2}{*}{ Sex } & & 52 & 52.0 \\
\cline { 2 - 4 } & Male & 48 & 48.0 \\
\cline { 2 - 4 } & Female & 57.5 & \pm 10.9 \\
\hline \multicolumn{2}{|l|}{ Mean age (years) } & 39 & -85 \\
\hline \multicolumn{2}{|l|}{ Range (min-max) } \\
\hline
\end{tabular}

Table-II: Diabetic retinopathy of the study patients $(\mathbf{n}=100)$

\begin{tabular}{|l|c|c|}
\hline Diabetic retinopathy & $\begin{array}{c}\text { Number of } \\
\text { patients }\end{array}$ & Percentage \\
\hline No DR & 34 & 34.0 \\
\hline PDR & 24 & 24.0 \\
\hline NPDR & 42 & 42.0 \\
\hline
\end{tabular}

Table-III : Diabetic nephropathy of the study patients $(n=100)$

\begin{tabular}{|l|c|c|}
\hline $\begin{array}{l}\text { Diabetic } \\
\text { nephropathy }\end{array}$ & $\begin{array}{c}\text { Number of } \\
\text { patients }\end{array}$ & Percentage \\
\hline Yes & 64 & 64.0 \\
\hline No & 36 & 36.0 \\
\hline
\end{tabular}

Table-IV: Investigation of the study patients $(n=100)$

\begin{tabular}{|l|c|c|}
\hline Investigation & $\begin{array}{c}\text { Number } \\
\text { of patients }\end{array}$ & Percentage \\
\hline HTN & 69 & 69.0 \\
\hline Smoker & 21 & 21.0 \\
\hline BM $(\mathrm{kg} / \mathrm{m} 2)$ & 26.0 & \pm 3.0 \\
\hline FBS $(\mathrm{mmol} / \mathrm{l})$ & 7.5 & \pm 2.8 \\
\hline 2HABS $(\mathrm{mmol} / \mathrm{l})$ & 11.7 & \pm 4.8 \\
\hline HbAlC $(\%)$ & 7.4 & \pm 1.8 \\
\hline SBP $(\mathrm{mmHg})$ & 135.8 & \pm 21.7 \\
\hline DBP $(\mathrm{mmHg})$ & 81.9 & \pm 11.9 \\
\hline Triglycerides $(\mathrm{mg} / \mathrm{dl})$ & 180.9 & \pm 97.2 \\
\hline Total cholesterol $(\mathrm{mg} / \mathrm{dl})$ & 192.1 & \pm 31.6 \\
\hline LDL $(\mathrm{mg} / \mathrm{dl})$ & 104.7 & \pm 34.3 \\
\hline eGFR $(\mathrm{mg} / \mathrm{dl})$ & 42.2 & \pm 38.3 \\
\hline Serum creatinine $(\mathrm{mg} / \mathrm{dl})$ & 1.8 & \pm 0.9 \\
\hline
\end{tabular}

Table V Association between diabetic retinopathy with diabetic nephropathy $(n=100)$

\begin{tabular}{|l|c|c|c|c|c|}
\hline \multirow{2}{*}{$\begin{array}{l}\text { Diabetic } \\
\text { retinopathy }\end{array}$} & \multicolumn{4}{|c|}{ Diabetic nephropathy } & \multirow{2}{*}{ p value } \\
\cline { 2 - 5 } & \multicolumn{2}{|c|}{ Yes } & \multicolumn{2}{|c|}{ No } & \multirow{2}{*}{} \\
\cline { 2 - 5 } & $\mathrm{n}$ & $\%$ & $\mathrm{n}$ & $\%$ & \\
\hline Yes & 47 & 73.4 & 19 & 52.8 & $0.036 \mathrm{~s}$ \\
No & 17 & 26.6 & 17 & 47.2 & \\
\hline
\end{tabular}

\section{DISCUSSION}

In this study showed more than half $(52.0 \%)$ of the patients were male and $48.0 \%$ were female. The mean age was found $57.5 \pm 10.9$ years with range from 39 to 85 years. Similar observation was found Lee et al. ${ }^{5}$ study they observed the mean age was found $64.51 \pm 11.47$ years and $48.7 \%$ were male. Ahmed et al. ${ }^{2}$ also found the mean age was $58.8 \pm 10.7$ years. Romero-Aroca et al. ${ }^{6}$ study reported that the mean age was found $47.16 \pm 11.05$ years with range from 23 to 59 years. Approximately half $(52.7 \%)$ of the patients were female and $47.3 \%$ were male.

In this study observed that the majority (42.0\%) patients was found NPDR, 24(24.0\%) was PDR and 34(34.0\%) was no DR in diabetic retinopathy. The frequency of DR and PDR were $28.5 \%$ and $1.5 \% .^{7}$ Epidemiologic study observed in Spain, which reported that the prevalence of DR, microalbuminuria, and overt nephropathy to be 
$26.11 \%, 17.78 \%$, and $6.74 \%$, respectively, in type $2 \mathrm{DM}^{7}$ Reddy et al. ${ }^{1}$ reported among 54 Diabetic Retinopathy patients, 12(22.3\%) had Mild NPDR; 16(29.6\%) had Moderate NPDR; 16(29.6\%) had Severe NPDR; 10(18.5\%) had PDR.

In present study showed the majority (64.0\%) patients had diabetic nephropathy and 36(36.0\%) had not diabetic nephropathy. Ahmed et al. $^{2}$ reported diabetic nephropathy was found 102 patients and 114 had not diabetic nephropathy. Reddy et al. ${ }^{1}$ observed out of 54 Diabetic Nephropathy patients, $18(33.4 \%)$ had No DR; 8(14.8\%) had Moderate NPDR; $8(14.8 \%)$ had Severe NPDR; 20(37\%) had PDR. Aziz observed diabetic nephropathy was found $37.0 \%$ patients and $63.0 \%$ had not diabetic nephropathy. ${ }^{9}$ Jeng et al. ${ }^{10}$ reported 10692 patients were found diabetic nephropathy, whereas without diabetic nephropathy was 42761 patinets.

In this study showed sixty nine (69.0\%) patients were hypertension and 21(21.0\%) was smoker. Mean BMI was found $26.0 \pm 3.0 \mathrm{~kg} / \mathrm{m}^{2}$, FBS was $7.5 \pm 2.8 \mathrm{mmol} / \mathrm{l}, 2 \mathrm{HABS}$ was $11.7 \pm 4.8 \mathrm{mmol} / \mathrm{l}$, HbAlc was $7.4 \pm 1.8$ percent, systolic blood pressure was $135.8 \pm 21.7 \mathrm{mmHg}$, diastolic blood pressure was found $81.9 \pm 11.9$, triglycerides was $180.9 \pm 97.2 \mathrm{mg} / \mathrm{dl}$, total cholesterol was $192.1 \pm 31.6$ $\mathrm{mg} / \mathrm{dl}$, LDL was $104.7 \pm 34.3 \mathrm{mg} / \mathrm{dl}$, eGFR was $42.2 \pm 38.3$ $\mathrm{mg} / \mathrm{dl}$ and serum creatinine was $1.8 \pm 0.9 \mathrm{mg} / \mathrm{dl}$. Lee et al. ${ }^{5}$ reported $73.0 \%$ patients were hypertension and $18.70 \%$ were smoker. FBS was $144.8 \pm 43.6 \mathrm{mg} / \mathrm{dl}$, HbAlc was $7.56 \pm 1.50$ percent, systolic blood pressure was $132.7 \pm 17.8$ $\mathrm{mmHg}$, diastolic blood pressure was $76.3 \pm 13.2$, triglycerides was $180.3 \pm 127.9 \mathrm{mg} / \mathrm{dl}$, total cholesterol was $186.3 \pm 37.8 \mathrm{mg} / \mathrm{dl}$, LDL was $105.2 \pm 33.9 \mathrm{mg} / \mathrm{dl}$, eGFR was $83.36 \pm 22.70 \mathrm{ml} / \mathrm{min} / 1.73 \mathrm{~m}^{2}$ and serum creatinine was $0.93 \pm 0.45 \mathrm{mg} / \mathrm{dl}$. Chen et al. ${ }^{11}$ observed that the predicting competence of microalbuminuria and moderately compact GFR on predicting the development of retinopathy among 487 type 2 diabetic patients. During the mean follow up of 6.6 years, they found that patients with microalbuminuria and estimated GFR $>60$ $\mathrm{mL} / \mathrm{min} / 1.73 \mathrm{~m}^{2}$ had a threefold increase in risk compared with those with normoalbuminuria and estimated GFR $30-59.9 \mathrm{~mL} / \mathrm{min} / 1.73 \mathrm{~m}^{2}$. Reddy et al. ${ }^{1}$ observed among 54 patients of Diabetic Retinopathy, 26(48.2\%) had good control with $\mathrm{HbA1C}<7 \%$; $28(51.8 \%)$ had poor control with $\mathrm{HbA1C}>8 \%$. Out of 54 Diabetic Nephropathy patients, 14(25.9\%) had good control with $\mathrm{HbA1C}<7 \%$; $40(74.1 \%)$ had poor control with HbA1C > $\%$.
Almost three fourth (73.4\%) patients was found diabetic retinopathy in diabetic retinopathy and $27(54.0 \%)$ in without diabetic retinopathy. The difference was statistically significant $(\mathrm{p}<0.05)$ between two groups. Ahmed et al. ${ }^{2}$ the frequency of nephropathy among individuals with retinopathy was $35.6 \%$. The regression model analysis showed significant association between nephropathy and development of retinopathy. Lee et al. ${ }^{5}$ association between DR (both DR itself and PDR) and DN (both microalbuminuria and overt nephropathy) is significant in the univariate $\mathrm{x}^{2}$ test. A number of studies provide evidence that DR may be independently associated with the development of microalbuminuria and hence be a powerful predictor for the progression of renal damage in DM patients. ${ }^{12-15}$ Multivariate logistic regression reported that patients with DR were 4.37 times more probable to have DN as those without DR. Schmechel and Heinrich ${ }^{16}$ indicated that patients with DR exhibited proteinuria more commonly than did those without DR. Villar et al. ${ }^{13}$ also demonstrated that DR was one of the most important risk factors for the development of incipient nephropathy in normoalbuminuric, normotensive patients with either type 1 or type $2 \mathrm{DM}$.

Different studies have shown the prevalence of PDR, rather than DR itself, is a risk factor for DN (microalbuminuria $^{8,17,18}$ and overt nephropathy ${ }^{8,18}$ ). Chen et al. ${ }^{19}$ reported that a microalbuminuria threshold of $10.7 \mathrm{mg} / 24$ $\mathrm{h}$, which was within the conventional 'normal range', can predict the increased risk for diabetic retinopathy development. Reddy et al. ${ }^{1}$ out of 54 Diabetic Retinopathy patients, 28 (51.8\%) patients had DN, 26 patients (48.2\%) had no evidence of DN. Out of 54 Diabetic Nephropathy patients, 36(66.6\%) had DR; 18(33.4\%) had No evidence of DR. In a study conducted by Prakash et al. ${ }^{20}$ noted that 4 of $8(50 \%)$ cases without DR had DN. It should be pointed out that absence of retinopathy cannot exclude the presence of Diabetic Nephropathy.

\section{CONCLUSIONS}

This study found that Diabetic Nephropathy has a significant association with the occurrence of Diabetic Retinopathy in persons with Type II DM.

\section{REFERENCES}

1. Reddy YJ, Banoth M, Reddy YG, Eslavath R. A Study on Correlation of Diabetic Retinopathy In Relation To Diabetic Nephropathy in Type II DM Patients Journal of Evidence based Medicine and Healthcare 2015;2: 4909-17. 
2. Ahmed MH, Elwali ES, Awadalla H, Almobarak AO. The relationship between diabetic retinopathy and nephropathy in Sudanese adult with diabetes: population based study, Diab Met Syndr: Clin Res Rev 2017;717:1-4.

3. Lam DW, LeRoith D. The worldwide diabetes epidemic. Curr. Opin. Endocrinol. Diabetes Obes. 2012;19(2):93-6.

4. Manaviat MR, Afkhami M, Shoja MR. Retinopathy and microalbuminuria in type II diabetic patients. BMC Ophthalmol. 2004;4:9.

5. Lee WJ, Sobrin L, Lee MJ, Kang MH, Seong M, Cho $\mathrm{H}$. The relationship between diabetic retinopathy and diabetic nephropathy in a population-based study in Korea (KNHANES V-2, 3). Invest Ophthalmol Vis Sci. 2014; 55: 6547-53.

6. Romero-Aroca P, Baget-Bernaldiz M, Reyes-Torres J, Fernandez-Ballart J, Plana-Gil N, Mendez-Marin I et al. Relationship between diabetic retinopathy, microalbuminuria and overt nephropathy, and twenty-year incidence follow-up of a sample of type 1 diabetic patients. Journal of Diabetes and Its Complications 2012; 26: 506-12.

7. Zhang X, Saaddine JB, Chou CF, Cotch MF, Cheng YJ, Geiss LS, et al. Prevalence of diabetic retinopathy in the United States, 2005-2008. JAMA. 2010;304: 649-56.

8. Pedro RA, Ramon SA, Marc BB, Juan FB, Isabel MM. Prevalence and relationship between diabetic retinopathy and nephropathy, and its risk factors in the north-east of Spain, a population-based study. Ophthalmic Epidemiol. 2010;17: 251-65.

9. Aziz KMA. Association of Diabetic Retinopathy and Maculopathy with Elevated HbA1c, Blood Pressure, Serum Creatinine, Microalbuminuria, Spot Urine Protein, Nephropathy and Diabetic Kidney Disease. An Experience from Data Analysis of 10,580 Diabetic Patients. J Endocrinol Diab. 2018; 5(1): 1-11.

10. Jeng CJ, Hsieh YT, Yang CM, Yang CH, Lin CL, Wang IJ. Diabetic Retinopathy in Patients with Diabetic Nephropathy: Development and Progression. PLoS ONE 2016; 11(8): e0161897.

11. Chen YH, Chen HS, Tarng DC. More impact of microalbuminuria on retinopathy than moderately reduced GFR among type 2 diabetic patients. Diabetes Care 2012; 35: 803-08.

12. El-Asrar AM, Al-Rubeaan KA, Al-Amro SA, Moharram OA, Kangave D. Retinopathy as a predictor of other diabetic complications. Int Ophthalmol. 2001;24:1-11.

13. Villar G, Garcia Y, Goicolea I, Vazquez JA. Determinants of development of microalbuminuria in normotensive patients with type 1 and type 2 diabetes. Diabetes Metab. 1999;25:246-54.

14. Stephenson JM, Fuller JH, Viberti GC, Sjolie AK, Navalesi R. Blood pressure, retinopathy and urinary albumin excretion in IDDM: the EURODIAB IDDM Complications Study. Diabetologia. 1995; 38:599-603.

15. Rossing P, Hougaard P, Parving HH. Risk factors for development of incipient and overt diabetic nephropathy in type 1 diabetic patients: a 10-year prospective observational study. Diabetes Care. 2002;25:859-64.

16. Schmechel H, Heinrich U. Retinopathy and nephropathy in insulin-treated diabetic patients in relation to the type of diabetes. Diabetes Metab. 1993;19:138-42.

17. Romero-Aroca P, Mendez-Marin I, Baget-Nernaldiz M, Fernendez-Ballart J, Santos-Blanco E. Review of the relationship between renal and retinal microangiopathy in diabetes mellitus patients. Curr Diabetes Rev. 2010;6:88-101.

18. Romero P, Salvat M, Fern'andez J, Baget M, Martinez I. Renal and retinal microangiopathy after 15 years of follow-up study in a sample of Type 1 diabetes mellitus patients. J Diabetes Complications. 2007; 21:93-100.

19. Chen H, Zheng Z, Huang Y, Guo K, Lu J, Zhang L, $\mathrm{Yu} \mathrm{H}$, et al. A microalbuminuria threshold to predict the risk for the development of diabetic retinopathy in type 2 diabetes mellitus patients. PLoS ONE 2012;7:e36718.

20. Prakash J, Lodha M, Singh SK, Vohra R, Raja R, Usha. Diabetic Retinopathy is A Poor Predictor of Type of Nephropathy in Proteinuric Type 2 Diabetic Patients. J Assoc Physicians India, 2007;55:412-16. 